\title{
Observations and scaling of tidal mass transport across the lower Ganges-Brahmaputra delta plain: implications for delta management and sustainability
}

\author{
Richard Hale ${ }^{1}$, Rachel Bain ${ }^{2}$, Steven Goodbred Jr. ${ }^{2}$, and Jim Best ${ }^{3}$ \\ ${ }^{1}$ Dept. of Ocean, Earth, and Atmos. Sci., Old Dominion University, Norfolk, VA, USA \\ ${ }^{2}$ Earth and Environmental Sciences Dept., Vanderbilt University, Nashville, TN, USA \\ ${ }^{3}$ Departments of Geology, Geography \& GIS, Mechanical Science and Engineering and Ven Te Chow \\ Hydrosystems Laboratory, University of Illinois, Urbana, IL, USA \\ Correspondence: Richard Hale (rphale@odu.edu)
}

Received: 16 August 2018 - Discussion started: 19 September 2018

Revised: 28 December 2018 - Accepted: 12 January 2019 - Published: 12 March 2019

\begin{abstract}
The landscape of southwest Bangladesh, a region constructed primarily by fluvial processes associated with the Ganges River and Brahmaputra River, is now maintained almost exclusively by tidal processes as the fluvial system has migrated east and eliminated the most direct fluvial input. In natural areas such as the Sundarbans National Forest, year-round inundation during spring high tides delivers sufficient sediment that enables vertical accretion to keep pace with relative sea-level rise. However, recent human modification of the landscape in the form of embankment construction has terminated this pathway of sediment delivery for much of the region, resulting in a startling elevation imbalance, with inhabited areas often sitting $>1 \mathrm{~m}$ below mean high water. Restoring this landscape, or preventing land loss in the natural system, requires an understanding of how rates of water and sediment flux vary across timescales ranging from hours to months. In this study, we combine time series observations of water level, salinity, and suspended sediment concentration with ship-based measurements of large tidal-channel hydrodynamics and sediment transport. To capture the greatest possible range of variability, cross-channel transects designed to encompass a $12.4 \mathrm{~h}$ tidal cycle were performed in both dry and wet seasons during spring and neap tides.

Regional suspended sediment concentration begins to increase in August, coincident with a decrease in local salinity, indicating the arrival of the sediment-laden, freshwater plume of the combined Ganges-BrahmaputraMeghna rivers. We observe profound seasonality in sediment transport, despite comparatively modest seasonal variability in the magnitude of water discharge. These observations emphasize the importance of seasonal sediment delivery from the main-stem rivers to this remote tidal region. On tidal timescales, spring tides transport an order of magnitude more sediment than neap tides in both the wet and dry seasons. In aggregate, sediment transport is flood oriented, likely as a result of tidal pumping. Finally, we note that rates of sediment and water discharge in the tidal channels are of the same scale as the annually averaged values for the Ganges and Brahmaputra rivers. These observations provide context for examining the relative importance of fluvial and tidal processes in what has been defined as a quintessentially tidally influenced delta in the classification scheme of Galloway (1975). These data also inform critical questions regarding the timing and magnitude of sediment delivery to the region, which are especially important in predicting and preparing for responses of the natural system to ongoing environmental change.
\end{abstract}




\section{Introduction}

The world's great deltas are currently threatened by a variety of factors, including global sea-level rise (Overeem and Syvitski, 2009), overpopulation (Ericson et al., 2006), changes in sediment supply (Syvitski, 2003; Syvitski and Milliman, 2007; Anthony et al., 2015; Darby et al., 2016; Best, 2019), and other human-related activities such as water diversions, flood control structures, and groundwater and hydrocarbon extraction (Syvitski et al., 2009). The GangesBrahmaputra-Meghna (GBM) delta is one of the most heavily populated regions that is undergoing locally accelerated sea-level rise $\left(\sim 0.5 \mathrm{~cm} \mathrm{yr}^{-1}\right.$; Higgins et al., 2014$)$ due to a combination of natural and anthropogenic factors including eustatic sea-level change, tectonic subsidence, fine-grained sediment compaction, and groundwater extraction (Overeem and Syvitski, 2009; Syvitski, 2008; Steckler et al., 2010). In addition, when factors such as tidal amplification due to anthropogenic reworking of the distributary channel network are considered, the relative rate of sea-level rise can exceed $1.6 \mathrm{~cm} \mathrm{yr}^{-1}$ (Pethick and Orford, 2013). Furthermore, the future viability of the delta is threatened by the proposed construction of dams and water diversions associated with India's National River Linking Project, which, if completed as proposed, could drastically reduce sediment delivery to Bangladesh (Higgins et al., 2018).

Restoration of land-surface elevation in many populated areas in the GBM delta is already necessary due to the relative loss in elevation that has occurred since the widespread construction of embankments during the 1960s to 1980s. Both planned (tidal river management) and unplanned (embankment failures) flooding of local polders (the embanked islands) has demonstrated the capacity of the natural system for effective sediment transport and deposition, with decimeters of annual accretion observed during recent breach events (Khadim et al., 2013; Auerbach et al., 2015; Kamal et al., 2018; Darby et al., 2018). One of the most important strategies that has been forwarded to reduce the threat of unintended inundations in SW Bangladesh is a plan for polder management (Brammer, 2014). However, many questions concerning potential management strategies remain, not the least of which are an accurate quantification of total available sediment mass and an understanding of the tidal processes involved in its transport and deposition. Toward these goals, the present study provides observation-based calculations of water and sediment transport through a major tidal channel in the delta across spring-neap tidal cycles and seasonal timescales, with the goal of identifying the timing and magnitude of mass sediment exchange between the different tidal channels. Not considered in the present study are the potential impacts of tropical cyclones, which directly impact Bangladesh 0.3-1.5 times per year (Murty et al., 1986; Alam et al., 2003; Saha and Khan, 2014) and can significantly affect the local landscape (Auerbach et al., 2015). The results presented herein are considered in the context of prior re- search concerning sediment accumulation and rates of channel infilling to better understand the role of tidal mass transport within the lower GBM delta plain.

\section{Background}

Much of the low-lying coastal region of SW Bangladesh is under threat of long-term inundation (Auerbach et al., 2015; Brown and Nicholls, 2015). The risk is particularly acute for islands that were embanked ("poldered") in the 1960s and 1970s as part of a program designed to increase the area of arable land through the prevention of tidal inundation in agricultural areas (Islam, 2006; Nowreen et al., 2014). Approximately $5000 \mathrm{~km}$ of polder embankments were built by hand, generating $9000 \mathrm{~km}^{2}$ of new farmland, but also eliminating the semi-diurnal exchange of water and sediment between the tidal channels and tidal platform (Islam, 2006; Nowreen et al., 2014). As a result, sediment resupply pathways have been effectively terminated and the former floodplain surface in these regions now lies $1.0-1.5 \mathrm{~m}$ below mean high water due to a combination of sediment starvation, enhanced compaction, and tidal-range amplification (Auerbach et al., 2015; Pethick and Orford, 2013).

In contrast to the poldered landscape, the adjacent mangrove system of the Sundarbans National Forest is primarily inundated during spring high tides, and its sedimentation and vegetation are keeping pace with sea-level rise (Rogers et al., 2013; Auerbach et al., 2015). Protecting the Sundarbans National Forest is of critical importance, as coastal wetlands and mangroves provide irreplaceable ecosystem services including storm-surge buffering (Uddin et al., 2013; Marois and Mitsch, 2015; Hossain et al., 2016; Sakib et al., 2015), serving as effective carbon traps (Mcleod et al., 2011; Alongi, 2014; Pendleton et al., 2012), and perhaps even helping to combat the impacts of ocean acidification (Yan, 2016).

For the GBM delta, a unit-scale analysis of mass balance (Rogers et al., 2013) suggests that the annual sediment load of the GBM river system $\left(\sim 1.1 \mathrm{Gt} \mathrm{yr}^{-1}\right)$ is sufficient to aggrade the entire delta system at rates $\geq 0.5 \mathrm{~cm} \mathrm{yr}^{-1}$ and thus provides potential to keep pace with moderately high rates of sea-level rise. Such aggradation, of course, requires effective dispersal of riverine sediment to disparate regions of the delta. Recent research suggests a close coupling of discharge at the river mouth to sediment deposition in the remote delta plain by way of tidal exchange (Allison and Kepple, 2001; Rogers et al., 2013; Auerbach et al., 2015; Wilson et al., 2017). Such tidally supported sedimentation yields mean accretion rates of $\sim 1 \mathrm{~cm} \mathrm{yr}^{-1}$, with local observations regularly reaching $3-5 \mathrm{~cm} \mathrm{yr}^{-1}$, which together indicate robust sediment delivery to the Sundarbans and SW coastal region (Rogers et al., 2013; Rogers and Overeem, 2017). Thus, as the principal conduit for sediment that can maintain the elevation of this region, an understanding and quantification of the tidal water and sediment exchange is essential to fore- 
see impacts of accelerated sea-level rise and the potential for mitigation.

\section{Methods}

\subsection{Study area}

Our research concerns a network of tidal channels located approximately $80 \mathrm{~km}$ from the coast along the Pussur River system, itself one of five similarly sized tidal distributary networks (Fig. 1). Tidal exchange extends $>120 \mathrm{~km}$ inland of the coast along the Pussur River, with one branch ultimately connecting to the Gorai River, a distributary of the mainstem Ganges River (Fig. 1). The tidal range along the Pussur River approaches its maximum in the study area at 4$5 \mathrm{~m}$ for the spring tidal range compared with $3-3.5 \mathrm{~m}$ on the coast at Hiron Point. The area is also societally relevant, lying at the transition from the pristine Sundarbans Forest to the embanked polders near the formerly active shipping port of Mongla and cyclone- and flood-impacted island of Polder 32 (labeled P32 in Fig. 1; Auerbach et al., 2015).

Within this area, our observations were collected in the primary tidal channel of the Shibsa River and two of its major bifurcations that connect with the Pussur channel, the Dhaki River and Bhadra River (Fig. 1). The Shibsa River is the largest of these channels, with local widths of $1-2 \mathrm{~km}$ compared to $0.25-0.8$ and $0.15-0.3 \mathrm{~km}$ for the Dhaki and Bhadra, respectively. At its eastern extent, the Dhaki River connects to the Pussur, serving as the first major cross-channel to link the Shibsa and Pussur River channels after they bifurcate $\sim 60 \mathrm{~km}$ to the south (Fig. 1). At its upstream extent, the Pussur tidal channel connects with the downstream mouth of the Gorai River, which delivers a water discharge of $\sim 3000 \mathrm{~m}^{3} \mathrm{~s}^{-1}$ during the monsoon season and decreasing to $\sim 0 \mathrm{~m}^{3} \mathrm{~s}^{-1}$ during the dry season (Winterwerp and Giardino, 2012). Salinity in the study area ranges from 0-1 PSU during the monsoon to 20-30 PSU during the dry season (Shaha and Cho, 2016; Ayers et al., 2017). This seasonal variation in salinity is controlled by local runoff, freshwater discharge from the Gorai River, and to a much larger extent, the magnitude of the regional discharge plume of the GBM rivers (Rogers et al., 2013).

\subsection{Hydrodynamic observations}

To establish tidal stage and capture surface-water elevations during the hydrodynamic surveys, pressure sensors were deployed at multiple locations across the study area (Fig. 1). All sensors were deployed as close to low water as possible and recorded at 5 or $10 \mathrm{~min}$ intervals. Periods of subaerial sensor exposure (of up to $150 \mathrm{~min}$ at low tide) were interpolated using a robust ordinary least-squares method provided by Grinsted (2008). The agreement between measurement and prediction was generally good, with the predicted range being 0.98 of the measured range for a given time period, thus suggesting that the interpolated data are both reasonable and conservative. The values reported herein are of the interpolated values. Tidal range, water temperature, and conductivity have also been monitored continuously since 2014 at the Sutarkhali station (Fig. 1b), with an optical backscatter sensor (OBS) calibrated to measure suspended sediment concentration (SSC) added in late March 2015. Prior to deployment in the tidal channel, this OBS was used to measure vertical profiles of SSC on the Shibsa River, with simultaneous water samples being collected to calibrate the instrument response to SSC. Water samples were filtered using preweighed $0.4 \mu \mathrm{m}$ nitrocellulose filters and washed with freshwater to remove salts. The filters were then dried overnight and reweighed to determine the volume concentration of sediment. The OBS measurements were calibrated by comparing the voltage response observed in the field with the measured concentrations from the same time and location in a method modified from Ogston and Sternberg (1999). Correlation between filtered samples and instrument voltage was strong, with an average $r$ squared value of $0.83 \pm 0.1$. While the sediment concentrations recorded by this near-bed instrument are not directly comparable to the depth-averaged measurements made during the present cross-channel surveys, we herein use these data to extend our understanding of system behavior between the dry and monsoon seasons. For a broader context, data from the sensors deployed at the $\mathrm{Su}$ tarkhali station are also compared to monthly averaged water discharge for the Ganges and Brahmaputra rivers for the period 1980-2000 based on data from the Bangladesh Water Development Board and Ganges River sediment discharge data digitized from Lupker et al. (2011).

To quantify water and sediment flux in this area of the tidal transport system, cross-channel hydrodynamic surveys were conducted during spring and neap tidal conditions at two transects on the Shibsa River during the dry (March 2015) and wet (August-September 2015) seasons. An additional wet season transect was also conducted during moderate tides on the Pussur River. On the Shibsa River, the southern transect was located south of the poldered landscape and entirely within the confines of the Sundarbans Forest (Fig. 1). The northern transect was located $\sim 12 \mathrm{~km}$ upstream in the poldered region, just south of the Dhaki-Shibsa confluence and adjacent to Polder 32 to the east and Polder 10-12 to the west (Fig. 1b). Two secondary channels are present between these transect locations that divert water onto the Sundarbans tidal platform and associated creek network. Dry season surveys at both the southern and northern transects took place during peak neap (15-16 March) and spring (21$22 \mathrm{March}$ ) tides. During the ensuing monsoon season, spring tides were measured on 30-31 August (southern transect) and 2 September (northern transect), followed by neap tides on 7 and 8 September (northern and southern transects, respectively). Surveys lasted for 11-13 h as conditions allowed, encompassing approximately one-half of a tidal cycle (i.e., one high and one low tide). Because this system is largely 

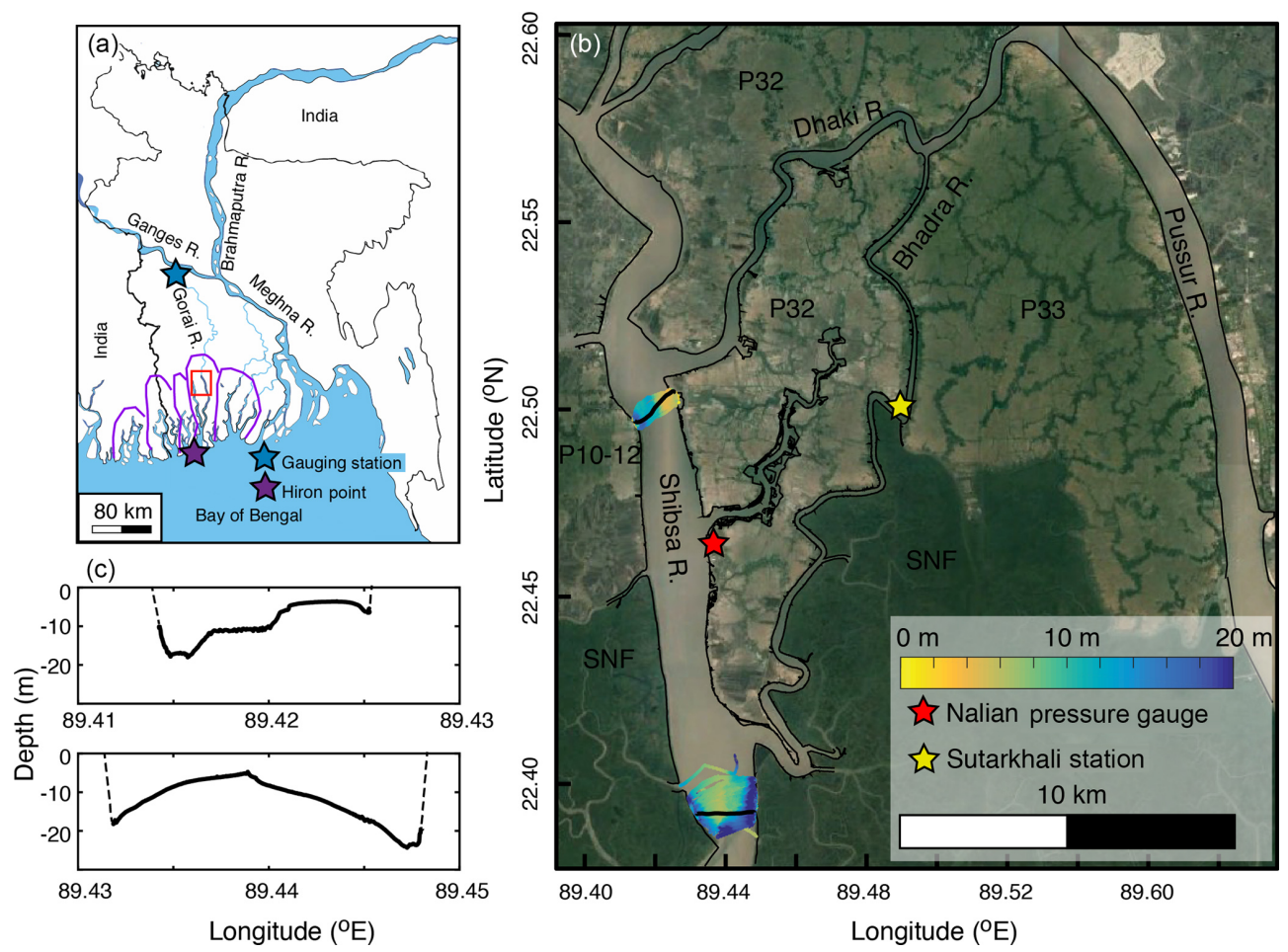

Figure 1. (a) Location of Bangladesh and the specific region of interest for this study, as well as the approximate outlines of the five major tidal distributary basins of the SW delta in purple. (b) Satellite image of P-32 study area, with bathymetry overlain in the regions of the northern and southern transects. Long-term and short-term pressure sensor locations are also identified. (c) Characteristic river cross sections for the northern and southern transects. The specific transects used for these cross sections are highlighted in black in (b).

semi-diurnal with a minimal mixed component, we are confident that this time interval was long enough to accurately describe the system dynamics.

The surveys were conducted using SonTek M9 multifrequency ADCPs to collect flow-perpendicular observations of current velocity and direction. Data were collected at $1 \mathrm{~Hz}$ using both 1.0 and $3.0 \mathrm{MHz}$ transducers, resulting in vertical bins ranging in height from $0.1-1.0 \mathrm{~m}$. From these values, total discharge was calculated by integrating velocity over space and time. River conventions are used for presenting velocity and discharge data, wherein positive values refer to the ebb or downstream direction and negative values to the flood or upstream transport. A typical survey day included 50-60 individual river crossings at the transect location, measuring cumulative discharge in both directions across the channel. Examples of cross-channel transects of velocity and SSC used to compute instantaneous water and sediment discharge can be found in Fig. 2. Because surveys could only be conducted during daylight hours and as weather conditions allowed, discharge is interpolated to complete a $12.4 \mathrm{~h}$ tidal cycle, which is the average tidal cycle duration in the area (range: 11.9-13.1 h). By assuming that the change in tidal prism is negligible between consecutive tides, as suggested by the similarity in tidal elevations (Fig. 3), we can tile measurements in $12.4 \mathrm{~h}$ increments and interpolate using a cubic spline. Working conditions were particularly challenging during the monsoon season, resulting in especially short-duration survey days. In the absence of measured discharge, we use a mass balance approach to constrain the magnitude of the missing tidal-prism data. For the monsoon season spring tides, we treat the region between the southern and northern transects and the southern Bhadra River as a closed system with no long-term ( $>1$ semi-diurnal period) water storage. Using measured Bhadra River discharge values and assuming a negligible to slightly southerly directed net flux through the adjacent Sundarbans allows us to determine the likely range of values for the unmeasured ebb prism at the southern transect. For the monsoon season neap tides, we consider the larger region bounded by the southern transect to the southwest, the Pussur River below the Dhaki River confluence to the southwest, and the Bangladesh Water Development Board gauging station at the Gorai Railway Bridge $\sim 275$ river $\mathrm{km}$ to the north. Balancing the measured net flux through the Pussur River and the recorded upstream discharge of the Gorai River of $3000 \mathrm{~m}^{3} \mathrm{~s}^{-1}$ with the measured ebb prism at the southern transect allows us to estimate the missing southern-transect flood prism. We then repeated this spring tide procedure to estimate the unmeasured neap flood prism at the northern transect. 

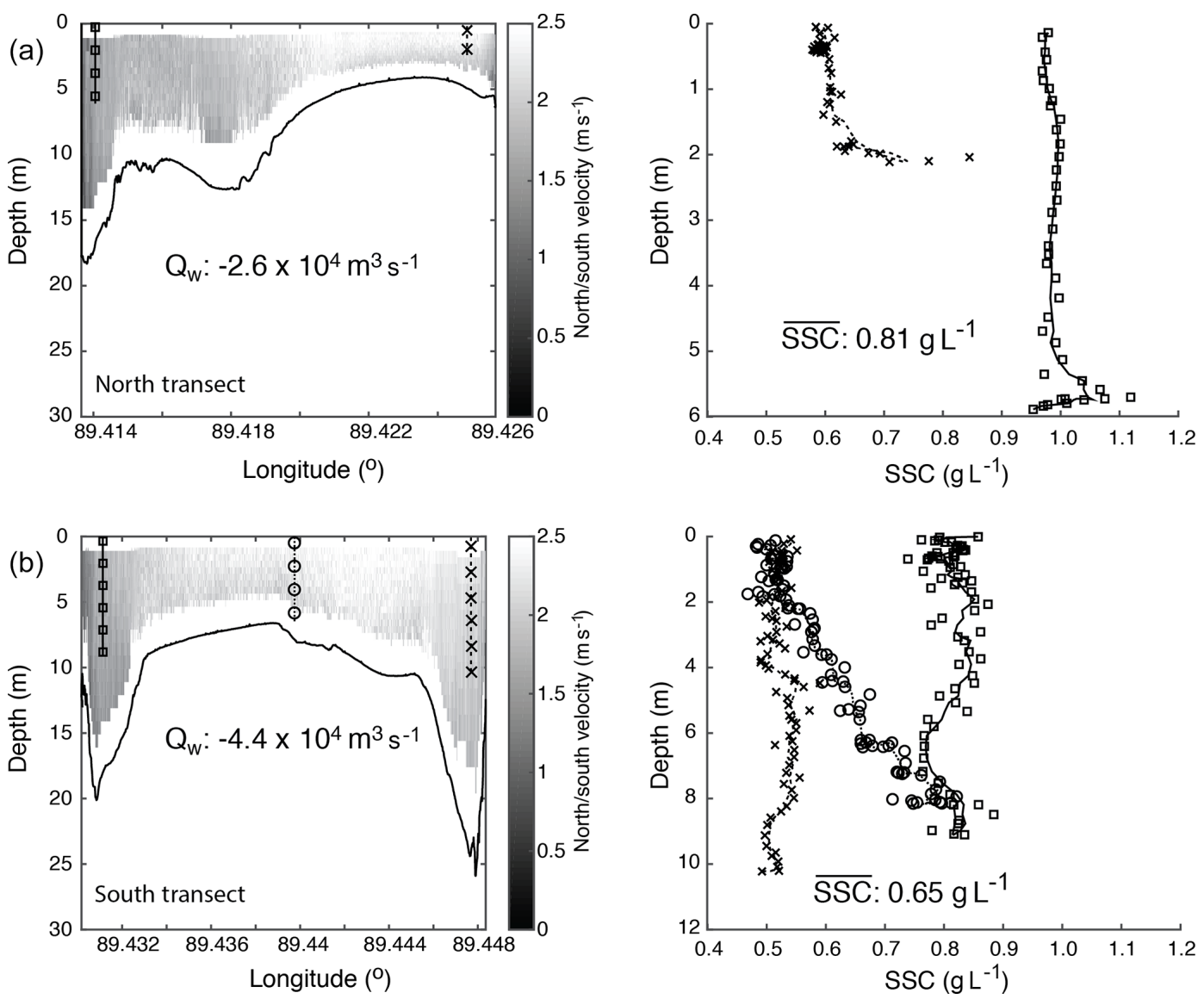

Figure 2. Example channel cross sections of velocity and SSC collected near maximum ebb-oriented tides during the wet season at the north (a) and south (b) transects. Velocity measurements are spatially integrated to compute water discharge. SSC are averaged, with the product of velocity and SSC used to compute sediment discharge.

\subsection{Sediment observations}

In addition to water discharge, observations of SSC along the transect lines were made using a combination of filtered water samples and optical backscatter (OBS) measurements. While the exact sampling method varied depending on available instrumentation and river conditions, the general approach involved collecting OBS profiles to the maximum possible depth $(<10 \mathrm{~m})$ at either two (northern transect) or three (southern transect) locations along the channel edges and centerline (Figs. 1, 2). OBS measurements were supplemented by simultaneous water samples (100$200 \mathrm{~mL}$ ) collected from various depths using a Niskin sampler, which were used to calibrate the OBS as described above (Sect. 3.1).

In order to calculate total sediment fluxes, the vertically and horizontally distributed SSC observations collected for each channel cross section were averaged to produce a series of temporally discrete SSC values over the course of one tidal cycle (Figs. 2, 4). This spatial averaging appears suitable because the variance was considerably smaller than the temporal variability associated with tidal discharge and strong sea- sonal contrasts. Using wet season data as an example, the average standard deviation of SSC through time at one sample location was $0.2 \mathrm{~g} \mathrm{~L}^{-1}$, while the average standard deviation of SSC between stations at any given time was $0.13 \mathrm{~g} \mathrm{~L}^{-1}$. When conditions did not allow samples to be collected at depths below the water surface, a scaling factor of 1.25 was applied to account for the higher subsurface SSC, which we determined by the relationship between depth-averaged concentrations and surface concentrations from the other available data. Similarly, measurements from 15 March (dry season neap tide) were only collected at depths of 5 and $15 \mathrm{~m}$ and were thus scaled by a factor of 0.81 to be comparable to other measurements that included surface SSC values.

An important caveat for all SSC measurements is that we present data collected primarily from the upper water column and not sampled isokinetically due to instrument limitations and high current velocities. Thus, our values principally represent suspended load and do not account for bedload transport, which likely represents an additional component of total sediment transport. As with our water-discharge measurements, SSC values were calculated over an entire tidal cy- 
cle by repeating a measured time series in $12.4 \mathrm{~h}$ increments, then interpolating using a cubic spline. From these values, the integrated product of water discharge and SSC yields net sediment flux, which we compute using the time series for each component as calculated using the aforementioned methods.

\section{Results}

\subsection{Long-term pressure and OBS}

At our long-term station deployed in a secondary tidal channel (Fig. 1), recorded water-level variations show tidal-period excursions with a range of 1.8 to $4.8 \mathrm{~m}$ over the 12 months of observation (Fig. 3). This variance is, of course, driven primarily by the fortnightly spring-neap tidal cycle, but there is also a seasonal variability showing the monsoon period to have a reduced tidal range compared with the dry season. In this case, the neap tidal range is $\sim 10 \%$ less during the monsoon season, and the spring tidal range is as much $\sim 20 \%$ less, accounting for a nearly $1 \mathrm{~m}$ difference $(3.9 \mathrm{~m}$ vs. $4.8 \mathrm{~m}$ ). This reduced range in the monsoon season, however, is not manifested in the elevation of high-tide water levels, which remained largely consistent between seasons. Rather, the difference is caused by higher water levels during low tide (Fig. 3), which has the effect of truncating the tidal range and yielding an overall higher mean water level. These higher low-water levels associated with the monsoon suggest that they are tied to regional freshwater drainage and discharge. In addition, another contributing factor could be the seasonally reversing monsoon wind stresses, but such a setup should enhance high water levels as well, suggesting that they are not the primary cause. Although further research on this topic is needed, these distinctions are important herein for understanding the behavior of the tidal delta plain, as landscape elevations in this region are closely tied to mean high-tide water levels, and not mean sea level (Auerbach et al., 2015). Thus, as first demonstrated by Pethick and Orford (2013), the monthly mean tide-gauge data often used to track seasonal to interannual variations in water level may have relatively little bearing on the tidal inundation period and sedimentation rates that control tidal-platform elevation (Rogers et al., 2013).

The arrival of fully freshwater (wet season) conditions occurs in July, following the peak in Brahmaputra River water discharge and roughly coincident with peak Ganges River water discharge (Fig. 4). Coupled with our long-term pressure gauge, the OBS sensor recorded relatively constant, but low, mean SSC from the late dry season into the early monsoon period (late March through July), with weak but noticeable spring-neap variability ranging from $\sim 0.01$ to $0.20 \mathrm{~g} \mathrm{~L}^{-1}$ (Fig. 3). However, moving into peak monsoon season, SSC increases markedly from early August through September, concurrent with the Ganges River sediment discharge peak (Figs. 2, 3). Individual measurements regularly exceeded $0.50 \mathrm{~g} \mathrm{~L}^{-1}$ during this time, with max- ima $>2.5 \mathrm{~g} \mathrm{~L}^{-1}$ (Fig. 3). SSC variability around the semidiurnal tide and spring-neap cycles was greatly enhanced compared with that during the dry season, with SSC values during spring tidal cycles exceeding those observed during neap conditions by a factor of $2-10$. By the end of observations in October 2015, SSC began to drop to levels similar to those observed in mid-August $\left(0.01-1.0 \mathrm{~g} \mathrm{~L}^{-1}\right.$; Fig. 3), but on average remained well above those of the dry season. For comparison, the mean annual SSC of the main-stem GangesBrahmaputra River is $\sim 1 \mathrm{~g} \mathrm{~L}^{-1}$, and depth-averaged values in the main estuary mouth and on the inner shelf commonly range $2-5 \mathrm{~g} \mathrm{~L}^{-1}$ during high river discharge (Barua et al., 1994; Ali et al., 2007). In total, SSC values well in excess of $1 \mathrm{~g} \mathrm{~L}^{-1}$ are regularly observed during the wet season from the main-stem river to the inner shelf and into the tidal channels of the lower delta plain. These results support previous evidence for the strong coupling of seasonal river discharge with penecontemporaneous sedimentation in the remote tidal delta plain (Rogers et al., 2013).

\subsection{Hydrography - water discharge}

Dry season tidal range on the Shibsa River, as measured at Nalian near the northern transect (Fig. 1b), varied from $2.3 \mathrm{~m}$ during the neap minima to $5.6 \mathrm{~m}$ during spring maxima (Fig. 3). The tidal period was slightly longer during neap tides than spring tides $(12.9 \mathrm{~h}$ vs. $12.3 \mathrm{~h}$ ), and the mixed component of the semi-diurnal tide was more pronounced, with consecutive tidal ranges varying by as much as $0.55 \mathrm{~m}$ during neap tides versus $0.23 \mathrm{~m}$ during spring tides (Fig. 3). During the monsoon fieldwork, the tidal range was 2.4 and $4.2 \mathrm{~m}$ for neap and spring tides, respectively. As with the dry season, total tidal period during neap tides was slightly longer than spring tides $(12.8 \mathrm{~h}$ vs. $12.0 \mathrm{~h})$. The mixed semi-diurnal variability was again greater during neap tides as well, which varied by as much as $0.25 \mathrm{~m}$, while spring tide variability was typically $<0.10 \mathrm{~m}$ (Fig. 3).

In this study, we calculate the tidal prism by integrating water discharge over the individual ebb and flood limbs of the tide, with net discharge calculated as the difference between them. During the dry season, our observations captured both peak flood and ebb discharges, with interpolation being used over the remaining $<5-15 \%$ of the tidal cycle (Fig. 5). During the wet season, field conditions during several surveys limited our measurement to only a partial tidal cycle $(\sim 8-$ $9 \mathrm{~h}$ survey; Fig. 5). Only during northern-transect spring tides were conditions favorable for collecting observations of similar duration to the dry season ( $\sim 11 \mathrm{~h}$ survey; Fig. 5$)$. Within these limits, however, we have used conservative interpolation methods to generate error-bound estimates of total water discharge, the resulting patterns of which provide robust observations concerning system behavior (see Sect. 2; Fig. 5).

The average tidal-prism magnitudes for the northern and southern transects are $2.1 \pm 0.7 \times 10^{8}$ and $3.4 \pm 1.4 \times 10^{8} \mathrm{~m}^{3}$, respectively. Included in these averages are the absolute val- 

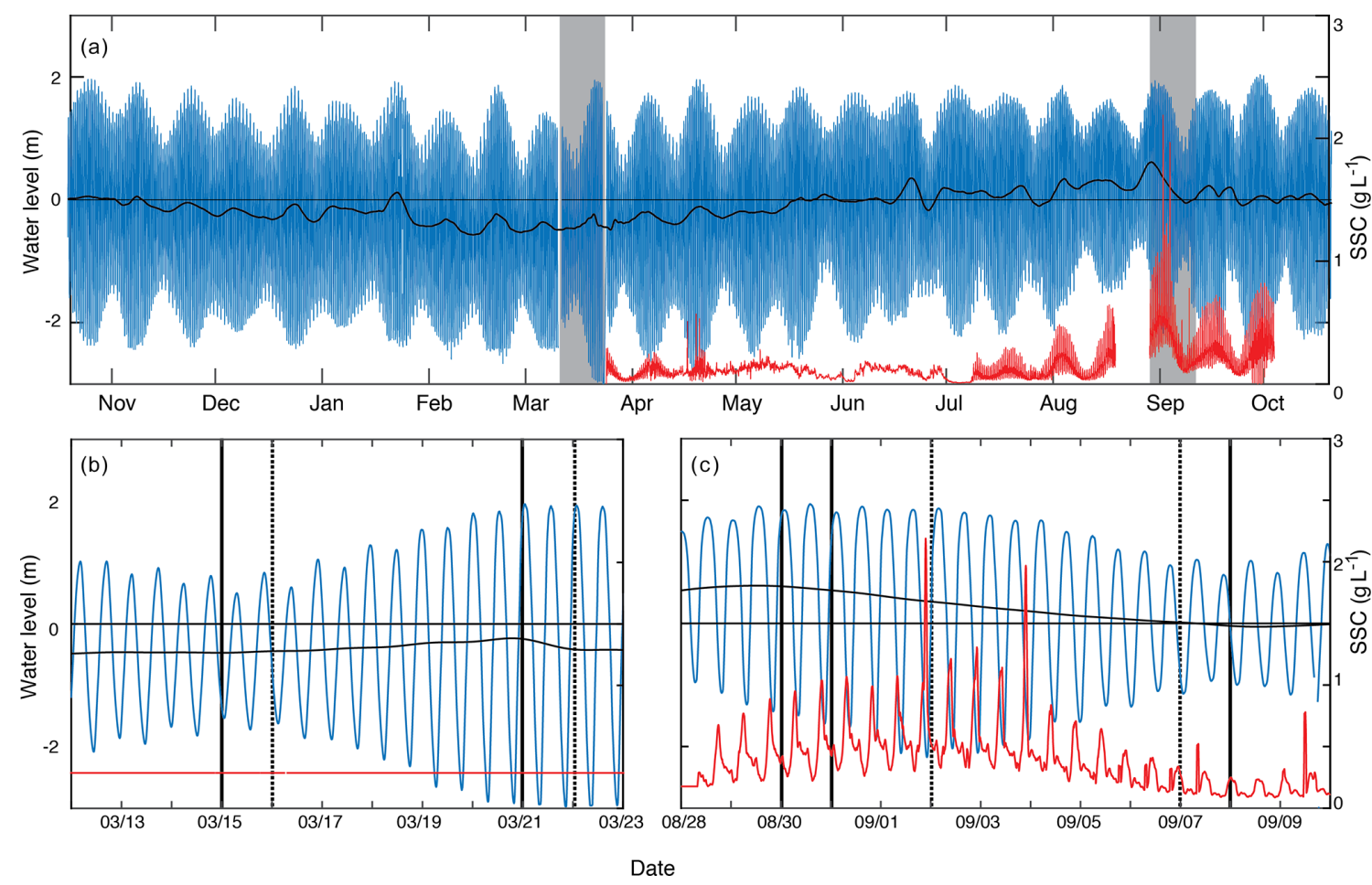

Figure 3. (a) Long-term water-level elevation (blue) and suspended sediment concentration (red) recorded at Sutarkhali. Black is the tidally filtered water level to highlight seasonal trends of relatively higher water during the monsoon, despite similar maximum tidal elevation. Also note the arrival of increased SSC associated with monsoon discharge of the GBM, beginning in August. Areas shaded in gray depict the periods of focused fieldwork, highlighted below in panels (b) and (c). Days on which transect measurements were recorded are noted with vertical black lines; solid are from the southern transect, and dashed are from the northern transect. In (b), the horizontal red line represents the maximum SSC observed in the spring-neap tidal cycle following our focused fieldwork, as SSC was not measured at this location previously.

ues of flood and ebb tidal prisms measured on spring and neap tides during both wet and dry seasons (Table 1). Thus, the tidal prism at the northern transect averages only $\sim 60 \pm$ $10 \%$ that of the southern transect regardless of season, even though they are located just $10 \mathrm{~km}$ apart. Most of this difference in discharge (ca. $80-100 \%$ ) can be balanced by water storage between the two locations, with the product of tidal range and area between transects being ca. $6.7 \times 10^{7} \mathrm{~m}^{3}$. Considering differences in seasonal discharge, results show that the neap ebb prism is $\sim 30 \%$ greater during the monsoon at both transects, despite having a smaller tidal range compared with the dry season survey. This difference of $4-6 \times 10^{7} \mathrm{~m}^{3}$ equates to an excess ebb discharge of $1800-2800 \mathrm{~m}^{3} \mathrm{~s}^{-1}$, which is about $45-70 \%$ of the mean monsoon discharge of the upstream Gorai River. We thus take the greater wet season ebb prism to simply reflect the addition of local freshwater discharge from the Gorai River (Table 1; Fig. 1).

Strictly speaking, defining a tidal regime as either ebb or flood dominant refers to the water velocity rather than discharge (Pethick, 1980; Brown and Davies, 2010). In the present study, however, we are interested in the net movement of water and sediment and thus refer to a particular discharge regime as either ebb or flood "dominated" or "ori- ented" based on the net tidal prism (i.e., the difference between ebb and flood discharge). With this in mind, our surveys suggest that the system varies between ebb and flood orientation across both tidal phase and season (Table 1). For example, both transects during the dry, spring and wet, and neap surveys show the average ebb tidal prism to be $26 \pm 16 \%$ larger than the flood limb. In contrast, the other two survey periods (dry, neap and wet, spring) yielded balanced to slightly flood-dominated tidal prisms $(9 \pm 8 \%)$. In summary, although our results on water balance are insufficient for a full understanding of the patterns, a key finding is that the ebb and flood tidal prisms rarely balance at this location. These tidal-prism asymmetries appear to be a salient characteristic of the complex, interconnected channel network of the GBMD tidal delta plain. Thus, even our limited observations require a lateral (east-west) exchange of water between the Shibsa and parallel Pussur channels (Fig. 1), which we presume to be driven by locally nonuniform tidal phasing within the channel network. Given these emergent circulation patterns, it is clear that individual channels do not operate as closed systems and exhibit local nonuniform mass exchange, providing a first indication of how the morphologic evolution of this tidal delta plain and its channel network may occur. 
Table 1. Measurements of sediment flux and tidal prism from the Shibsa River. Within each season, the bottom two rows represent measurements taken during spring tides.

\begin{tabular}{|c|c|c|c|c|c|c|c|c|}
\hline & \multirow[t]{2}{*}{ Transect } & \multirow{2}{*}{$\begin{array}{r}\text { Tidal } \\
\text { Range }(\mathrm{m})\end{array}$} & \multicolumn{3}{|c|}{ Tidal prism $\left(\mathrm{m}^{3}\right)$} & \multicolumn{3}{|c|}{ Sediment load (kg) } \\
\hline & & & $\mathrm{Ebb}$ & Flood & Net & Ebb & Flood & Net \\
\hline \multirow{4}{*}{ 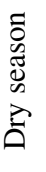 } & South & 2.1 & $2.00 \times 10^{8}$ & $-2.00 \times 10^{8}$ & $4.30 \times 10^{5}$ & $2.05 \times 10^{7}$ & $-4.70 \times 10^{7}$ & $-2.66 \times 10^{7}$ \\
\hline & North & 2.2 & $1.40 \times 10^{8}$ & $-1.50 \times 10^{8}$ & $-1.30 \times 10^{7}$ & $1.55 \times 10^{7}$ & $-2.37 \times 10^{7}$ & $-8.21 \times 10^{6}$ \\
\hline & South & 5.5 & $4.50 \times 10^{8}$ & $-4.30 \times 10^{8}$ & $2.30 \times 10^{7}$ & $1.83 \times 10^{8}$ & $-2.30 \times 10^{8}$ & $-4.69 \times 10^{7}$ \\
\hline & North & 5.7 & $3.10 \times 10^{8}$ & $-2.30 \times 10^{8}$ & $7.90 \times 10^{7}$ & $2.15 \times 10^{8}$ & $-1.90 \times 10^{8}$ & $2.49 \times 10^{7}$ \\
\hline \multirow{4}{*}{ 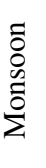 } & South & 2.7 & $2.64 \times 10^{8}$ & $-1.81 \times 10^{8}$ & $8.28 \times 10^{7}$ & $4.47 \times 10^{7}$ & $-3.89 \times 10^{7}$ & $5.77 \times 10^{6}$ \\
\hline & North & 2.2 & $1.83 \times 10^{8}$ & $-1.06 \times 10^{8}$ & $7.69 \times 10^{7}$ & $6.20 \times 10^{7}$ & $-4.12 \times 10^{7}$ & $2.08 \times 10^{7}$ \\
\hline & South & 4 & $4.71 \times 10^{8}$ & $-5.12 \times 10^{8}$ & $-4.16 \times 10^{7}$ & $3.20 \times 10^{8}$ & $-3.85 \times 10^{8}$ & $-6.50 \times 10^{7}$ \\
\hline & North & 3.9 & $2.40 \times 10^{8}$ & $-2.85 \times 10^{8}$ & $-4.43 \times 10^{7}$ & $2.54 \times 10^{8}$ & $-3.31 \times 10^{8}$ & $-7.65 \times 10^{7}$ \\
\hline
\end{tabular}

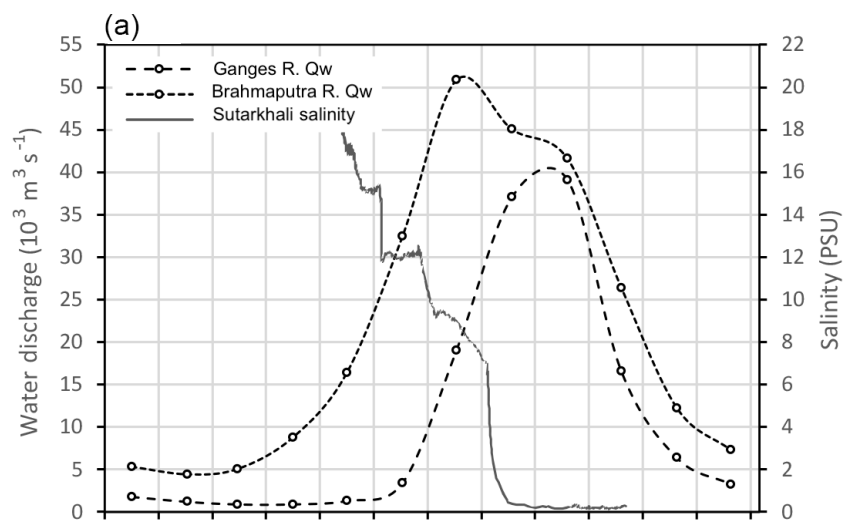

(b)

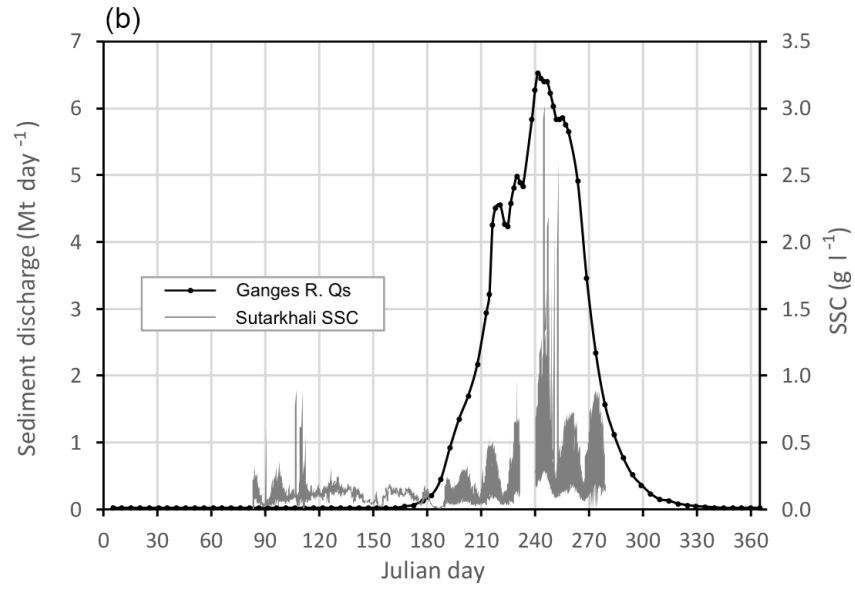

Figure 4. (a) Ganges and Brahmaputra River water discharge $\left(Q_{\mathrm{w}}\right)$ and salinity measured at Sutarkhali station, demonstrating the reduction in P-32 salinity associated with the arrival of freshwater from the GBM rivers. (b) Ganges River sediment discharge $\left(Q_{\mathrm{S}}\right)$ interpolated from Lupker et al. (2011) and SSC measured at Sutarkhali station, demonstrating the increase in local SSC coincident with the peak SSC discharge of the Ganges.
Although relative dominance between the ebb and flood tidal prisms persistently covaries (as described above), the mean and instantaneous water discharge $\left(\mathrm{m}^{3} \mathrm{~s}^{-1}\right)$ is almost always flood dominant (Fig. 6). This circumstance arises from the significant phase shift that occurs as the tide wave propagates up channel, resulting in a shorter flood period and thus higher peak discharge. From our measurements of instantaneous discharge across seasons and tidal conditions, we calculate mean ebb and flood discharges $\left(\mathrm{m}^{3} \mathrm{~s}^{-1}\right)$ for each transect (Fig. 6). Mean discharge for the northern transect is $\sim 9100 \mathrm{~m}^{3} \mathrm{~s}^{-1}$ on the flood and $8600 \mathrm{~m}^{3} \mathrm{~s}^{-1}$ on the ebb, and for the southern transect, mean flood and ebb discharges are $\sim 14600$ and $14200 \mathrm{~m}^{3} \mathrm{~s}^{-1}$, respectively. From these results, we observe that mean discharge at the northern transect is again $\sim 61 \pm 1 \%$ of that of the southern transect, as also recognized for the tidal prism. Another notable result is that the mean flood discharge $\left(\mathrm{m}^{3} \mathrm{~s}^{-1}\right)$ is $3-6 \%$ greater than on the ebb tide, despite the tidal prism generally being ebb dominant. This disparity is a function of the shallow-water distortion of the M2 tide, which produces an asymmetrical waveform with a steeper rising limb than falling limb, and a corresponding reduction in the duration of the flood tide by $\sim 60-90 \mathrm{~min}$.

\subsection{Hydrography - sediment transport}

Suspended sediment measurements collected during the hydrographic surveys show similar patterns to those of our long-term OBS station. Wet season sediment concentrations were generally $30-50 \%$ higher than during the dry season (Fig. 5). Much greater differences in SSC were observed, however, between neap and spring tidal conditions, with the latter concentrations being typically $\sim 3$-fold greater $(0.3-$ $1.5 \mathrm{~g} \mathrm{~L}^{-1}$ vs. $0.1-0.5 \mathrm{~g} \mathrm{~L}^{-1}$ ). These sediment concentrations, coupled with the water-discharge observations, were then extrapolated over the tidal cycle to generate estimates of the rates and magnitude of sediment transport (Table 1). Results show that integrated sediment transport over a tidal limb var- 


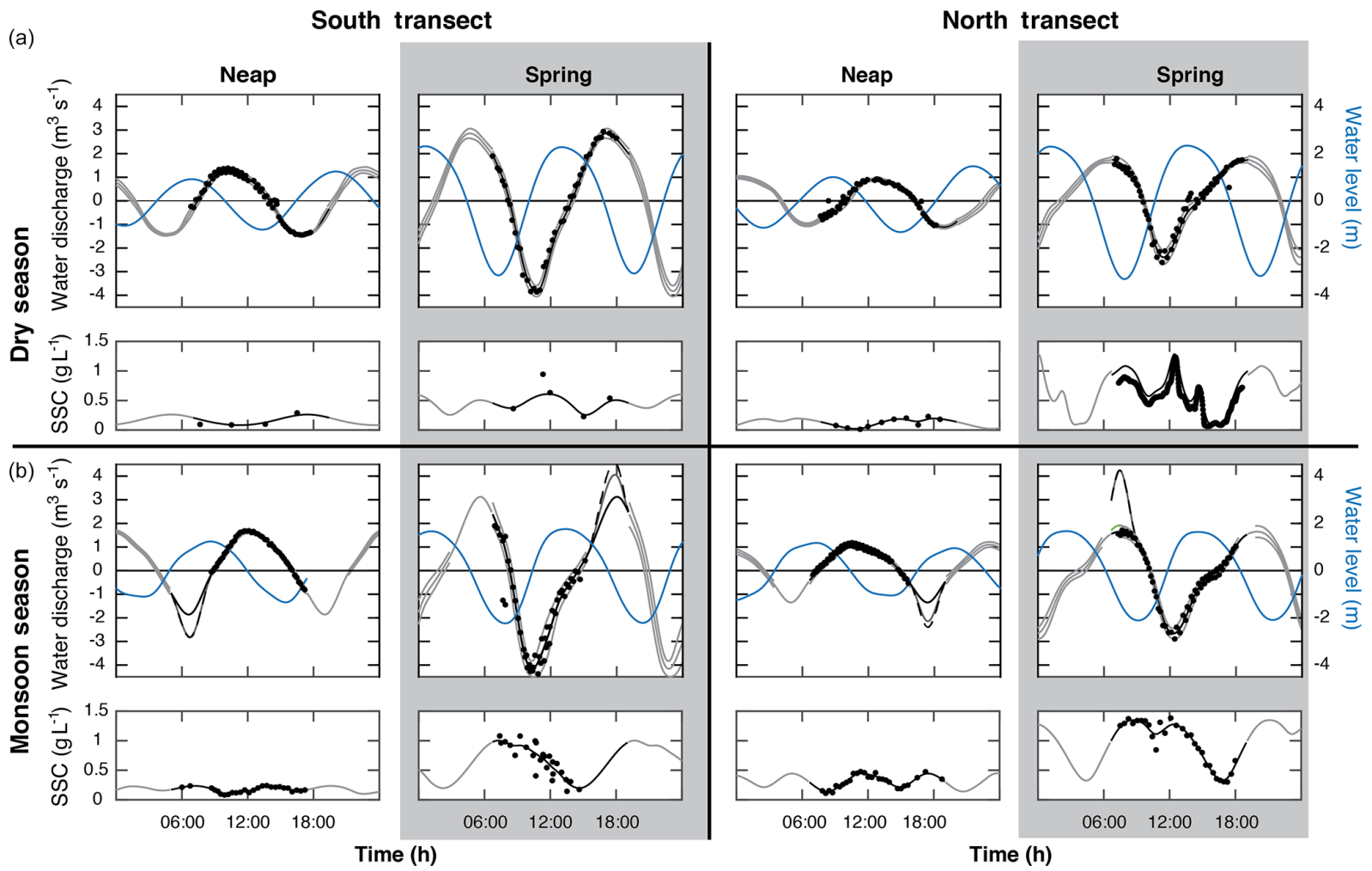

Figure 5. Instantaneous water discharge, water level, and depth and width-averaged SSC for each day of cross-channel transects. Dry season measurements are in (a), while monsoon season transects are in (b). Spring tides in either season are shaded in gray. The two left columns are southern measurements, and the two right columns are from the northern transect. Black dots correspond to specific measurements, while gray lines represent the estimated error tiled forwards and backwards by $12.4 \mathrm{~h}$. For discharge, dashed lines in the monsoon represent maxima based on extrapolations from the dry season ratio. While seemingly unreasonable, they are provided here for context.
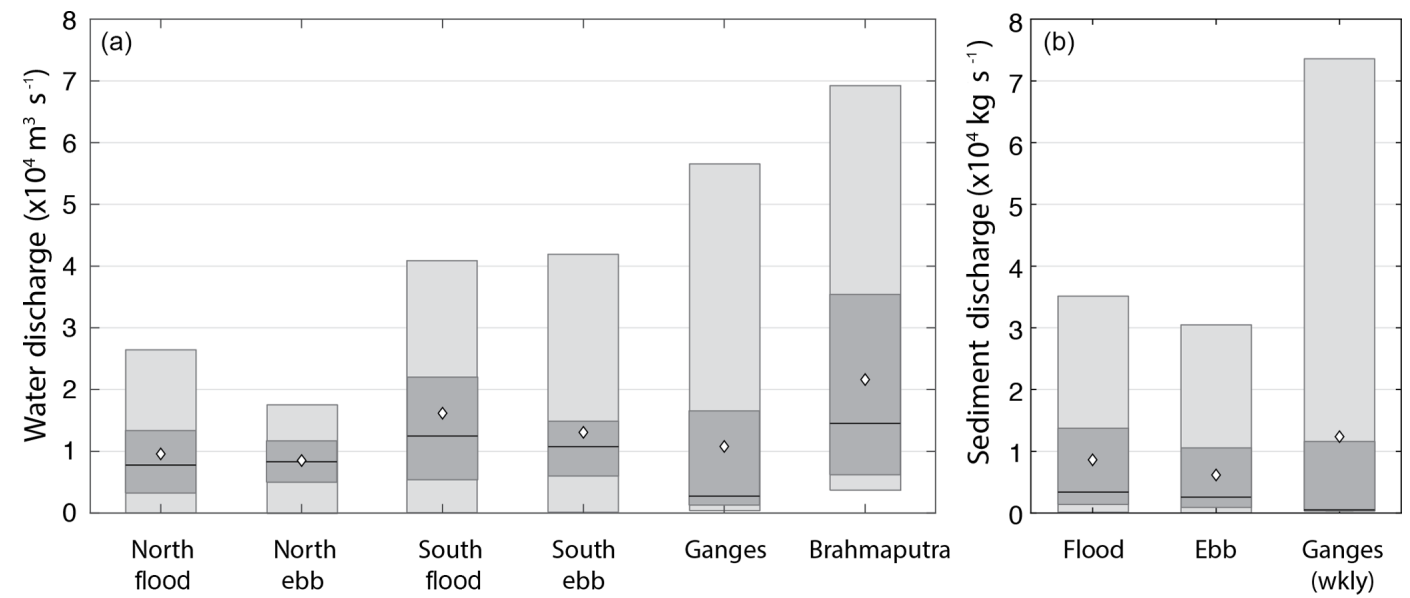

Figure 6. Comparison of mean (diamond), median (black line), 25th and 75th percentile (lower and upper limits of darkly shaded box), and total range (lightly shaded box) for water discharge (a) and sediment discharge (b). (a) Demonstration that median and mean discharge along either transect are comparable to those of either the Ganges or Brahmaputra River. (b) Demonstration that as with water, mean sediment discharge on both the flood and ebb tides is approximately the same as the weekly averaged Ganges sediment discharge. 
ied by more than an order of magnitude at both transects. Minima of $0.16 \times 10^{8} \mathrm{~kg}$ (north) and $0.2 \times 10^{8} \mathrm{~kg}$ (south) of sediment exchange were observed during the neap dry season ebb tide, with maxima during spring monsoon flood tides being an order of magnitude greater at $3.3 \times 10^{8} \mathrm{~kg}$ (north) and $3.9 \times 10^{8} \mathrm{~kg}$ (south). These values equate to mean rates of sediment transport ranging from $\sim 700 \mathrm{~kg} \mathrm{~s}^{-1}$ during neap dry season conditions to $\sim 17000 \mathrm{~kg} \mathrm{~s}^{-1}$ during monsoon season spring tides. Comparing the ebb and flood limbs of our surveys, the mean sediment discharge for the ebb tide is $5800 \mathrm{~kg} \mathrm{~s}^{-1}$ compared to $7800 \mathrm{~kg} \mathrm{~s}^{-1}$ for the flood tide, demonstrating an overall flood dominance in sediment transport.

These patterns are further supported by the net sediment transport values (i.e., ebb-flood; Table 1). For a given tidal cycle, net sediment transport was typically $10^{6}-10^{7} \mathrm{~kg}$, with magnitude varying largely with tidal phase and spring tides generating 1.5 to 3 times greater net transport than during neap tides (Table 1). Seasonally, net sediment transport rates were $\sim 30 \%$ greater during the wet season, similar to our observations of suspended sediment concentration. Finally, a comparison of net sediment transport with corresponding net water discharge shows the two to covary, as expected, with greater net water discharge resulting in greater net sediment transport (Fig. 7). However, an important attribute of this relationship reveals a significant bias toward flood-dominant sediment transport. Data show that even neutral to weakly ebb-dominant water discharge yields net sediment transport in the flood direction (Fig. 7). As noted for water discharge $\left(\mathrm{m}^{3} \mathrm{~s}^{-1}\right)$, this disparity is a function of the non-negligible tidal components beyond $\mathrm{M} 2$ that result in a shortened flood limb and extended ebb period (Fig. 3; Table 1). Together, mean sediment discharge and net sediment transport patterns thus indicate an overall flood-oriented asymmetry and net onshore transport of sediment.

\section{Discussion}

\subsection{Relative importance of tides and river}

The GBM tidal delta plain comprises a complex channel network that has been little studied and will require substantial investigation to be understood well. Nevertheless, results of the current study allow for numerous observations on the scaling and magnitude of tidal mass transport within this region, establishing a baseline for the role that tides play in defining the delta system, particularly in the southwest region away from direct fluvial inputs. To begin, we take an average of the flood and ebb tidal prisms measured at the two sites on the Shibsa River over both spring and neap tidal phases during wet and dry seasons and extrapolate the mean tidal prism over 1 year. In other words, an average $2.7 \times 10^{8} \mathrm{~m}^{3}$ of water passes through this region on each of the $\sim 705$ tides per year. This basic estimation accounts for an average $\sim 2 \times 10^{11} \mathrm{~m}^{3}$ of water annually conveyed through our

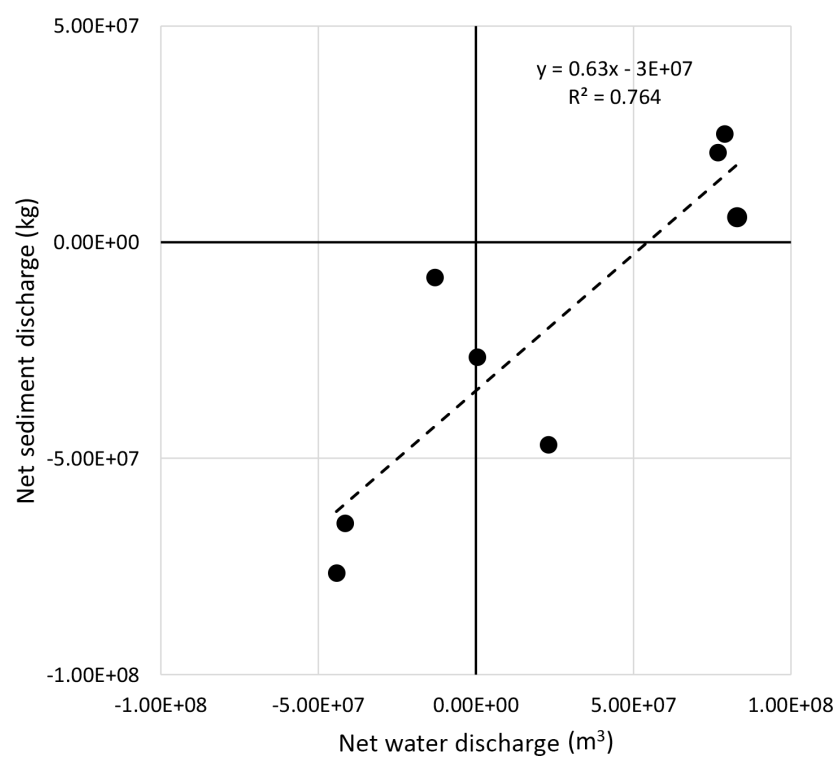

Figure 7. Net water discharge vs. net sediment discharge for all of the survey days on the Shibsa River. As expected, we observe a positive trend to this relationship. The negative $y$ intercept of the best-fit curve demonstrates the overall flood-oriented nature of sediment transport in this tidal channel.

survey locations $80 \mathrm{~km}$ inland of the coast. Furthermore, this mass exchange is principally tidal water, as the $50-75 \%$ of annual Gorai River discharge captured by the Shibsa River (i.e., $\sim 0.2 \times 10^{11} \mathrm{~m}^{3}$ ) accounts for only $10 \%$ of the total water exchange observed for that channel.

The significance of these observations from the upstream Shibsa River tidal channel becomes more apparent when compared with the main-stem GBM rivers. In this case, the $\sim 2 \times 10^{11} \mathrm{~m}^{3}$ of water conveyed annually through the upper Shibsa River is nearly $20 \%$ of the $\sim 11 \times 10^{11} \mathrm{~m}^{3}$ of total annual water discharge from the entire GBM watershed (Lupker et al., 2011; Fig. 4). This is an impressive exchange of mass through the upper reaches of a single tidal channel along the GBM tidal delta plain. For context, the Shibsa River comprises approximately half (by planform area) of the Pussur River tidal system (Fig. 1), itself just one of five major tidal drainages along the GBM tidal delta plain (Fig. 1). Taken together, these basins include $\sim 10$ tidal channels having a similar area (width $\times$ length) to the Shibsa River. We take the tidal flow through these systems to be broadly similar given the linear relationship between peak tidal discharge and the cross-sectional area of large tidal channels (Rinaldo et al., 1999), plus the fact that land-surface elevation and tidal range are similar across the region (Chatterjee et al., 2013). Thus, even at a first order, estimates of total mass transport across the tidal region would well exceed the $\sim 11 \times 10^{11} \mathrm{~m}^{3}$ total volume discharged by the main-stem GBM rivers.

The comparable values between our observations of tidal water exchange in this limited study area and the total 
freshwater discharge of the GBM rivers demonstrates how tides hold equivalence in controlling landscape development in the GBMD, which was suggested as far back as Galloway (1975). To further consider the geomorphic importance of tides to the GBMD, we make analogous estimations of sediment transport $\left(Q_{\mathrm{S}}\right)$ that supports land-surface aggradation and the dominant water discharge $\left(Q_{\text {dom }}\right)$ that controls tidal-channel morphology (Rinaldo et al., 1999). As done for water discharge, by taking the average of our tidal hydrography data for sediment transport, we calculate the mean annual exchange of suspended sediment through the Shibsa River tidal station to be $\sim 1 \times 10^{11} \mathrm{~kg}(\sim 100 \mathrm{Mt})$. For comparison, this estimate of sediment load is roughly $15 \%$ of the $\sim 700 \mathrm{Mt}$ of sediment annually discharged to the coast by the GBM rivers (Goodbred and Kuehl, 1999). Thus, if we extrapolate any similar transport value to the other nine GBM tidal channels, then the sediment exchange through the tidal channels is easily found to be comparable to the main river mouth. There is, of course, the important caveat that tidal sediment transport is not unidirectional, so this integrated exchange of tidal sediment is not a net flux as it is for river sediment discharge. Nevertheless, the relevant point is that local geomorphic reaches of the tidal delta plain have the opportunity for landscape building through tidal water and sediment exchange at a similar magnitude to the main-stem GBM rivers. This assertion is not surprising given the relative stability of the tidal delta plain, which experiences relatively little net erosion $\left(\sim 4 \mathrm{~km}^{2} \mathrm{yr}^{-1}\right.$, or $\sim 0.02 \%$ annual loss; Sarwar and Woodroffe, 2013) and is offset by widespread sediment deposition on both the land surface (Rogers et al., 2013) and in channels (Wilson et al., 2017).

From this study, we understand that tidal energy, independent of the main river mouth, accounts for a twice-daily exchange of a mass equivalent to $4-15 \%$ of the yearly averaged daily GBM river discharge. In primary channels, the magnitude of this exchange is controlled more by the springneap tidal variability than by the seasonal input of new material (Fig. 5). In the smaller Bhadra tidal channel, on the other hand, SSC variability demonstrates profound seasonality, presumably because discharge (and therefore stream power) is at least an order of magnitude smaller here than in the Shibsa River. This disparity is important when we consider land-building processes, as the majority of the Sundarbans Forest is plumbed by tidal channels on the scale of the Bhadra River or smaller. Storms may also play a role in remobilizing sediment from the shelf onto the tidal delta plain, as suggested by Hanebuth et al. (2013) in their study of ancient salt kilns buried along the coast. However, there are no observations of significant direct storm deposition from recent cyclones (Aila, 2009 and Sidr, 2007), such as that recognized from the offshore Bengal shelf and Swatch of No Ground canyon (e.g., Kudrass et al., 1998, 2018; Michels et al., 1998; Rogers and Goodbred, 2010). The potentially limited impact of storms on sedimentation and the channel network of the tidal delta plain may be due its frequent and per- sistent exposure to high sediment concentrations and strong currents $\left(>3 \mathrm{~m} \mathrm{~s}^{-1}\right)$ driven by the tides. Nevertheless, future research should aim to quantify storm inputs and their relative importance upon sedimentation and morphodynamics of the tidal delta plain.

These findings and discussion points emphasize the essential role that tides play in maintaining the largest portion of the GBM lower delta plain, which is not under direct river influence. However, despite the essential role of tides in mixing and dispersing sediment to large areas of the delta, the supply of sediment remains largely contemporaneous with seasonal fluvial discharge, especially in the secondary and tertiary channels that irrigate the Sundarbans. Together, the coupled system in which the GBM rivers deliver sediment that is subsequently redistributed by tidal energy is fundamentally responsible for the sustainability of this region relative to sea-level change (e.g., Angamuthu et al., 2018). A significant corollary of this fact is that a change in sediment supply from the GBM rivers, such as that proposed under India's National River Linking Project, could pose a serious threat to delta sustainability (Higgins et al., 2018; Best, 2019).

To summarize, as the central coastal region receives little direct water and sediment discharge from the GBM, the results herein emphasize that tidal exchange is the dominant geomorphic agent in the region with a mass and energy exchange of comparable or greater magnitude to the main-stem rivers. It is, of course, essential to recognize that most freshwater and sediment exchanged within the tidal system is ultimately sourced by the main rivers and that these are intrinsically coupled systems. Thus, the continued sustainability of the region will require the sustained delivery and exchange of water and sediment between the fluvial and tidal portions of the delta.

\subsection{Sedimentation in the Sundarbans and infilling of tidal channels}

Our observations of tidal sediment exchange provide a useful baseline for examining sedimentation in the Sundarbans and broader tidal delta plain, which are at risk from sea-level rise and inundation without an adequate supply of sediment. To date, the best estimate of total sedimentation in the Sundarbans is $1.1 \times 10^{11} \mathrm{~kg} \mathrm{yr}^{-1}(\sim 100 \mathrm{Mt}$ ) based on one season of direct sedimentation measures at 48 stations across the region (Rogers et al., 2013). This mass of sediment deposited in the Sundarbans is basically equivalent to the $\sim 100 \mathrm{Mt}$ of sediment that we observe transported through the Shibsa River transects. Thus, recalling that our local measurements likely capture just $5-10 \%$ of total suspended sediment transported through the tidal channels of the region, it becomes evident that there is generally adequate suspended sediment available to support regional sedimentation in the Sundarbans.

Another plausible implication is that there appears to be adequate sediment available for the restoration of land elevation within the poldered region, which is a major challenge 
facing coastal Bangladesh (Amir et al., 2013). Although a definitive answer remains to be determined, this general assertion is supported by observations of the rapid sedimentation that occurred on Polder 32 in the 2 years following the embankment failures caused by cyclone Aila in 2009 (Auerbach et al., 2015). Measurements at Polder 32 after these failures found an average of $37 \pm 17 \mathrm{~cm} \mathrm{yr}^{-1}$ of tidal sedimentation sustained over its 2-year exposure to tidal inundation, corresponding to a total annual deposition of $\sim 5 \mathrm{Mt}$. Based on inundation depth and period, this accounts for an average of $\sim 0.2 \mathrm{~g} \mathrm{~L}^{-1}$ of sediment extracted from the tidal waters that flooded the island during this time. This value compares to a mean suspended sediment concentration of $\sim 0.6 \mathrm{~g} \mathrm{~L}^{-1}$ measured during our hydrographic surveys, suggesting that roughly one-third of the tidal sediment inundating the landscape generated these very rapid sedimentation rates. Ultimately, limitations in the present data preclude a closed, precise sediment budget, but our collective observations over several different studies remain consistent in direction and magnitude. These indicate persistent and relatively rapid rates of deposition that are sustained by the largemagnitude conveyance of sediment through the tidal channels and ultimately supplied by seasonal discharge of the main-stem rivers (Rogers et al., 2013; Auerbach et al., 2015; this study).

Upstream of our transect sites, the landscape is almost entirely embanked by polder systems. With limited opportunity for sediment deposition on this formerly intertidal platform and with the resulting reduction or redistribution of the tidal prism upstream, channel sedimentation and infilling has become a major problem. Wilson et al. (2017) demonstrate that by preventing the inundation of the intertidal platform, poldering has reduced the tidal prism of the broader southwest region by as much as $1.4 \times 10^{9} \mathrm{~m}^{3}$. If we assume that this volume reduction is relatively evenly dispersed across the delta plain, then it would have led to a $25-50 \%$ reduction in the local tidal prism measured at our sites. These effects are at least partially responsible for the $\sim 1400 \mathrm{~km}$ of channel infilling that has taken place over the last few decades, resulting in the creation of new agriculture and aquaculture opportunities but also altering drainage, transportation routes, and feedback responses of the regional tidal hydrodynamics (Wilson et al., 2017). The mass of sediment that has infilled these channels is calculated to be $6.15 \times 10^{11} \mathrm{~kg}$, which would be $\sim 1.2 \times 10^{10} \mathrm{~kg} \mathrm{yr}^{-1}$ assuming a roughly constant rate (Wilson et al., 2017). Of these infilled channels, $\sim 15 \%$ $(\sim 200 \mathrm{~km})$ are part of the former channel network connecting upstream of our northern transect (Fig. 1). Thus, a proportional rate of sedimentation lost to these channels would be $\sim 0.18 \times 10^{10} \mathrm{~kg} \mathrm{yr}^{-1}$, which is $\sim 25 \%$ of the estimated $0.68 \times 10^{10} \mathrm{~kg}$ fluxing through the northern transect (to the north) each year. While this sediment exchange is 4 times greater than the expected total based on infilling rates from Wilson et al. (2017), it relies on the same previously described assumptions (i.e., no lateral exchange with neighbor- ing rivers, non-end-member flux reflecting an average of endmember conditions). More importantly, it appears that there is sufficient sediment available to continue infilling channels, and future studies should constrain whether this region is, in fact, infilling faster than other areas on the tidal delta plain, as this would hold important implications for regional navigation and hydrodynamic changes.

\section{Conclusions}

In the present study, we have measured tidal and seasonal variability associated with water discharge and suspended sediment concentration (SSC), and we used these observations to compute the magnitude of water and sediment exchange through a single tidal channel. As has been suggested previously, the wet season is found to exert a strong control on the timing and magnitude of sediment transport in this system, despite seemingly modest changes to the hydrodynamics. Indeed, despite a reduced tidal range and similar peak SSC, sediment transport during the monsoon is always of greater magnitude than during the dry season. Understanding this relationship is critical for planning any potential land recovery strategies in the future. The importance of the monsoon also provides a new perspective on the meaning of a "tidal delta". While it is clearly the tides that perform much of the work to shape the delta - including driving a net floodoriented direction of sediment flux - it is the seasonal influx of riverine sediment that allows this work to continue. Finally, this research demonstrates that the mass of sediment transported north of our study area is more than sufficient to fill channels and create additional land. Ideally, future landuse management strategies could divert some of this excess sediment into polder interiors through tidal river management (e.g., Seijger et al., 2018; Shampa and Pramanik, 2012; van Staveren et al., 2016) and allow this landscape to continue to prosper.

Data availability. Data used for this publication will be archived in the Marine Geoscience Data System http://www.marine-geo. org/tools/search/DataSets.php?data_set_uids=24710,24711 (last access: 28 February 2019, Hale et al., 2019a, b).

Sample availability. Samples from this publication are stored in the sedimentology laboratory at Vanderbilt University.

Author contributions. The experiment was designed by RH and $\mathrm{SG}$, with input from RB and JB. RH and RB led the field research efforts with support from SG and JB. RH wrote the majority of the paper and figures, with substantial input from SG. RB and JB also contributed to the paper and figures. 
Competing interests. The authors declare that they have no conflict of interest.

Acknowledgements. This work would not be possible without the support of our local collaborators, Kazi Matin Ahmed and Syed Humayun Akchter from Dhaka University, who oversaw in-country logistics and offered local guidance. We would also like to thank Abu Naser Hossain of the Forestry Crime Department for his help with permitting, Nasrul Islam Bachchu of Pugmark Tours, and the captain and crew of the M/V Bawali and M/L Mawali for their seemingly endless patience with our field logistics. We would also like to thank Md. Saddam Hossain, Abrar Hossain, Mynul Hassan, Carol Wilson, and Mike Reed for their field support. This research was supported by the US Office of Naval Research (N00014-11-1-0683) and the National Science Foundation (Coastal SEES no. 1600319). We are grateful to the external reviewers, Mead Allison and John Shaw, for their valuable insights and contributions to the strength of the final paper.

Edited by: Daniel Parsons

Reviewed by: Mead Allison and John Shaw

\section{References}

Alam, M. A., Hossain, M. A., and Shafee S.: Frequency of Bay of Bengal cyclonic storms and depressions crossing different coastal zones, Int. J. Climatol., 23, 1119-1125, 2003.

Ali, A., Mynett, A. E., and Azam, M. H.: Sediment dynamics in the Meghna estuary, Bangladesh: A model study, J. Waterw. Port Coast. Ocean Eng.-ASCE, 133, 255-263, 2007.

Allison, M. and Kepple, E.: Modern sediment supply to the lower delta plain of the Ganges-Brahmaputra River in Bangladesh, Geo-Mar. Lett., 21, 66-74, 2001.

Alongi, D. M.: Carbon cycling and storage in mangrove forests, Annu. Rev. Mar. Sci., 6, 195-219, 2014.

Amir, M. S. I. I., Khan, M. S. A., Khan, M. K., Rasul, M. G., and Akram, F.: Tidal river sediment management-A case study in southwestern Bangladesh, Int. J. Environm. Chem. Ecol. Geol. Geophys. Eng., 7, 176-185, 2013.

Angamuthu, B., Darby, S. E., and Nicholls, R. J.: Impacts of natural and human drivers on the multi-decadal morphological evolution of tidally-influenced deltas, Proc. Roy. Soc. A, 474, 20180396, https://doi.org/10.1098/rspa.2018.0396, 2018.

Anthony, E. J., Brunier, G., Besset, M., Goichot, M., Dussouillez, P., and Nguyen, V. L.: Linking rapid erosion of the Mekong River delta to human activities, Sci. Rep., 5, 14745, https://doi.org/10.1038/srep14745, 2015.

Auerbach, L. W., Goodbred Jr., S. L., Mondal, D. R., Wilson, C. A., Ahmed, K. R., Roy, K., Steckler, M. S., Small, C., Gilligan, J. M., and Ackerly, B. A.: Flood risk of natural and embanked landscapes on the GangesBrahmaputra tidal delta plain, Nat. Climate Change, 5, 153-157, https://doi.org/10.1038/NCLIMATE2472, 2015.

Ayers, J. C., George, G., Fry, D., Benneyworth, L., Wilson, C., Auerbach, L., Roy, K., Karim, M. R., Akter, F., and Goodbred, S.: Salinization and arsenic contamination of sur- face water in southwest Bangladesh, Geochem. Trans., 18, 4, https://doi.org/10.1186/s12932-017-0042-3, 2017.

Barua, D. K., Kuehl, S. A., Miller, R. L., and Moore, W. S.: Suspended sediment distribution and residual transport in the coastal ocean off the Ganges-Brahmaputra river mouth, Mar. Geol., 120, 41-61, 1994.

Best, J.: Anthropogenic stresses on the world's big rivers, Nat. Geosci., 12, 7-21, https://doi.org/10.1038/s41561-018-0262-x, 2019.

Brammer, H.: Bangladesh's dynamic coastal regions and sea-level rise, Clim. Risk Manage., 1, 51-62, 2014.

Brown, J. M. and Davies, A. G.: Flood/ebb tidal asymmetry in a shallow sandy estuary and the impact on net sand transport, Geomorphology, 114, 431-439, 2010.

Brown, S. and Nicholls, R. J.: Subsidence and human influences in mega deltas: the case of the Ganges-Brahmaputra-Meghna, Sci. Total Environ., 527, 362-374, 2015.

Chatterjee, M., Shankar, D., Sen, G. K., Sanyal, P., Sundar, D., Michael, G. S., Chatterjee, A., Amol, P., Mukherjee, D., Suprit, K., and Mukherjee, A.: Tidal variations in the Sundarbans estuarine system, India, J. Earth Syst. Sci., 122, 899-933, 2013.

Darby, S. E., Hackney, C. R., Leyland, J., Kummu, M., Lauri, H., Parsons, D. R., Best, J. L., Nicholas, A. P., and Aalto, R.: Fluvial sediment supply to a mega-delta reduced by shifting tropical-cyclone activity, Nature, 539, 276-279, https://doi.org/10.1038/nature19809, 2016.

Darby, S. E., Nicholls, R. J., Rahman, M. M., Brown, S., and Karim, R.: A Sustainable Future Supply of Fluvial Sediment for the Ganges-Brahmaputra Delta, in: Ecosystem Services for WellBeing in Deltas, 277-291, Palgrave Macmillan, Cham, 2018.

Ericson, J. P., Vörösmarty, C. J., Dingman, S. L., Ward, L. G., and Meybeck, M.: Effective sea-level rise and deltas: causes of change and human dimension implications, Global Planet. Change, 50, 63-82, 2006.

Galloway, W. E.: Process framework for describing the morphologic and stratigraphic evolution of deltaic depositional systems in: Deltas: models for exploration, edited by: Broussard, M. L., 87-98, Houston Geological Society, 1975.

Goodbred Jr., S. L. and Kuehl, S. A.: Holocene and modern sediment budgets for the Ganges-Brahmaputra river system: Evidence for highstand dispersal to flood-plain, shelf, and deep-sea depocenters, Geology, 27, 559-562, 1999.

Grinsted, A.: Tidal fitting toolbox (v 1.3.0.0), Matlab code, available at: https://www.mathworks.com/matlabcentral/ fileexchange/19099-tidal-fitting-toolbox?s_tid=srchtitle (last access: 1 October 2018), 2008.

Hale, R., Bain, R., Goodbred, S., and Best, J.: Uncalibrated Hydrographic Data from the Ganges-Brahmaputra Delta, Interdisciplinary Earth Data Alliance (IEDA), https://doi.org/10.1594/IEDA/324710, 2019a.

Hale, R., Bain, R., Goodbred, S., and Best, J.: Uncalibrated Hydrographic Data from the Ganges-Brahmaputra Delta, Interdisciplinary Earth Data Alliance (IEDA), https://doi.org/10.1594/IEDA/324711, 2019b.

Hanebuth, T. J. J., Kudrass, H. R., Linstadter, J., Islam, B., and Zander, A. M.: Rapid coastal subsidence in the central GangesBrahmaputra Delta (Bangladesh) since the 17th century deduced from submerged salt-producing kilns, Geology, 41, 987-990, 2013. 
Higgins, S. A., Overeem, I., Steckler, M. S., Syvitski, J. P., Seeber, L., and Akhter, S. H.: InSAR measurements of compaction and subsidence in the Ganges-Brahmaputra Delta, Bangladesh, J. Geophys. Res.-Earth Surf., 119, 1768-1781, 2014.

Higgins, S., Overeem, I., Rogers, K., and Kalina, E.: River linking in India: Downstream impacts on water discharge and suspended sediment transport to deltas, Elem. Sci. Anth., 6, p. 20, https://doi.org/10.1525/elementa.269, 2018.

Hossain, M. S., Dearing, J. A., Rahman, M. M., and Salehin, M.: Recent changes in ecosystem services and human well-being in the Bangladesh coastal zone, Reg. Environ. Change, 16, 429443, 2016.

Islam, M. R.: Managing Diverse Land Uses in Coastal Bangladesh: Institutional Approaches, Environment and livelihoods in tropical coastal zones, p. 237, 2006.

Kamal, A. S. M., Hossain, A., Hossain, B. M., Hassan, S. M., and Rashid, A. K. M.: Physical and Social Assessment of the Waterlogged Area and Suitability of the "Inclusive and Adaptive Tidal River Management Technique" to Alleviate Waterlogging in Southwest Bangladesh, Proc. Eng., 212, 760-767, 2018.

Khadim, F. K., Kar, K. K., Halder, P. K., Rahman, M. A., and Morshed, A. M.: Integrated water resources management (IWRM) impacts in south west coastal zone of Bangladesh and factfinding on tidal river management (TRM), J. Water Resour. Protect., 5, 38240, https://doi.org/10.4236/jwarp.2013.510098, 2013.

Kudrass, H. R., Michels, K. H., Wiedicke, M., and Suckow, A.: Cyclones and tides as feeders ofa submarine canyon off Bangladesh, Geology, 26, 715-718, 1998.

Kudrass, H. R., Machalett, B., Palamenghi, L., Meyer, I., and Zhang, W.: Sediment transport by tropical cyclones recorded in a submarine canyon off Bangladesh, Geo-Mar. Lett., 38, 481-496, 2018.

Lupker, M., France-Lanord, C., Lavé, J., Bouchez, J., Galy, V., Métivier, F., Gaillardet, J., Lartiges, B., and Mugnier, J. L.: A Rousebased method to integrate the chemical composition of river sediments: Application to the Ganga basin, J. Geophys. Res.-Earth Surf., 116, 1-24, 2011.

Marois, D. E. and Mitsch, W. J.: Coastal protection from tsunamis and cyclones provided by mangrove wetlands - a review, Int. J. Biodiv. Sci., Ecosyst. Serv. Manage., 11, 71-83, 2015.

Mcleod, E., Chmura, G. L., Bouillon, S., Salm, R., Björk, M., Duarte, C. M., Lovelock, C. E., Schlesinger, W. H., and Silliman, B. R.: A blueprint for blue carbon: toward an improved understanding of the role of vegetated coastal habitats in sequestering $\mathrm{CO}_{2}$, Front. Ecol. Environ., 9, 552-560, 2011.

Michels, K. H., Kudrass, H. R., and Hu, C.: The submarine delta of the Ganges- Brahmaputra?: cyclone-dominated sedimentation patterns, Mar. Geol., 149, 133-154, 1998.

Murty, T. S., Flather, R. A., and Henry, R. F.: The storm surge problem in the bay of Bengal, Prog. Oceanogr., 16, 195-233, https://doi.org/10.1016/0079-6611(86)90039-X, 1986.

Nowreen, S., Jalal, M. R., and Khan, M. S. A.: Historical analysis of rationalizing South West coastal polders of Bangladesh, Water Pol., 16, 264-279, 2014.

Ogston, A. S. and Sternberg, R. W.: Sediment-transport events on the northern California continental shelf, Mar. Geol., 154, 69-82, 1999.
Overeem, I. and Syvitski, J. P. M.: Dynamics and Vulnerability of Delta Systems: LOICZ Reports and Studies, No 35, GKSS Research Center, Geesthacht, p. 54, 2009.

Pendleton, L., Donato, D. C., Murray, B. C., Crooks, S., Jenkins, W. A., Sifleet, S., Craft, C., Fourqurean, J. W., Kauffman, J. B., Marbà, N., and Megonigal, P.: Estimating global "blue carbon" emissions from conversion and degradation of vegetated coastal ecosystems, PloS One, 7, e43542, https://doi.org/10.1371/journal.pone.0043542, 2012.

Pethick, J. S.: Velocity surges and asymmetry in tidal channels, Estuar. Coast. Mar. Sci. 11, 331-345, 1980.

Pethick, J. and Orford, J. D.: Rapid rise in effective sea-level in southwest Bangladesh: its causes and contemporary rates, Global Planet. Change, 111, 237-245, 2013.

Rinaldo, A., Fagherazzi, S., Lanzoni, S., Marani, M., and Dietrich, W. E.: Tidal networks: 3. Landscape-forming discharges and studies in empirical geomorphic relationships, Water Resour. Res., 35, 3919-3929, 1999.

Rogers, K. G. and Goodbred, S. L.: Mass failures associated with the passage of a large tropical cyclone over the Swatch of No Ground submarine canyon (Bay of Bengal), Geology, 38, 10511054, https://doi.org/101.1130/G41181.1, 2010.

Rogers, K. G. and Overeem, I.: Doomed to drown? Sediment dynamics in the human-controlled floodplains of the active Bengal Delta, Elementa: Sci. Anthrop., 6, 66, https://doi.org/10.1525/elementa.250, 2017.

Rogers, K. G., Goodbred Jr., S. L., and Mondal, D. R.: Monsoon sedimentation on the "abandoned" tide-influenced GangesBrahmaputra delta plain, Estuar. Coast. Shelf Sci., 131, 297-309, 2013.

Saha, M. K. and Khan, N.: Changing profile of cyclones in the context of climate change and adaptation strategies in Bangladesh, J. Bangladesh Inst. Plann., 7, 63-78, 2014.

Sakib, M., Nihal, F., Haque, A., Rahman, M., and Ali, M.: Sundarban as a Buffer against Storm Surge Flooding, World J. Eng. Technol., 3, 59-64, 2015.

Sarwar, M. G. M. and Woodroffe, C. D.: Rates of shoreline change along the coast of Bangladesh, J. Coast. Conserv., 17, 515-526, 2013.

Seijger, C., Datta, D. K., Douven, W., van Halsema, G., and Khan, M. F.: Rethinking sediments, tidal rivers and delta livelihoods: tidal river management as a strategic innovation in Bangladesh, Water Pol., 21, wp2018212, https://doi.org/10.2166/wp.2018.212, 2018.

Shaha, D. C. and Cho, Y. K.: Salt plug formation caused by decreased river discharge in a multi-channel estuary, Sci. Rep., 6, p. 27176, 2016.

Shampa, M. and Pramanik, I. M.: Tidal River Management (TRM) for Selected Coastal Area of Bangladesh to Mitigate Drainage Congestion, Int. J. Sci. Technol. Res., 1, 1-6, 2012.

Steckler, M. S., Nooner, S. L., Akhter, S. H., Chowdhury, S. K., Bettadpur, S., Seeber, L., and Kogan, M. G.: Modeling Earth deformation from monsoonal flooding in Bangladesh using hydrographic, GPS, and Gravity Recovery and Climate Experiment (GRACE) data, J. Geophys. Res.-Solid Earth, 115, B8, https://doi.org/10.1029/2009JB007018, 2010.

Syvitski, J. P.: Supply and flux of sediment along hydrological pathways: research for the 21 st century, Global Planet. Change, 39, 1-11, 2003. 
Syvitski, J. P.: Deltas at risk, Sustain. Sci., 3, 23-32, 2008.

Syvitski, J. P. and Milliman, J. D.: Geology, geography, and humans battle for dominance over the delivery of fluvial sediment to the coastal ocean, The J. Geol., 115, 1-19, 2007.

Syvitski, J. P., Kettner, A. J., Overeem, I., Hutton, E. W., Hannon, M. T., Brakenridge, G. R., Day, J., Vörösmarty, C., Saito, Y., Giosan, L., and Nicholls, R. J.: Sinking deltas due to human activities, Nat. Geosci., 2, 681-686, 2009.

Uddin, M. S., van Steveninck, E. D. R., Stuip, M., and Shah, M. A. R.: Economic valuation of provisioning and cultural services of a protected mangrove ecosystem: a case study on Sundarbans Reserve Forest, Bangladesh, Ecosyst. Serv., 5, 88-93, 2013.

van Staveren, M. F., Warner, J. F., Khan, M. S. A., and Shah Alam Khan, M.: Bringing in the tides. From closing down to opening up delta polders via Tidal River Management in the southwest delta of Bangladesh, Water Pol., 19, 147-164, 2016.
Wilson, C., Goodbred, S., Small, C., Gilligan, J., Sams, S., Mallick, B., and Hale, R.: Widespread infilling of tidal channels and navigable waterways in human-modified tidal deltaplain of southwest Bangladesh, Elem. Sci. Anth, 5, 78, https://doi.org/10.1525/elementa.263, 2017.

Winterwerp, J. C. and Giardino, A.: Assessment of increasing freshwater input on salinity and sedimentation in the Gorai river system, World Bank Proj., 1206292-000, https://doi.org/10.13140/2.1.1504.1286, 2012.

Yan, W.: Can mangroves buffer ocean acidification?, Eos, 97, https://doi.org/10.1029/2016EO053819, 2016. 